\title{
LOCAL LOW CARBON ECONOMY PLANS IN THE CONTEXT OF LOW CARBON RURAL DEVELOPMENT
}

\author{
Paweł Wiśniewski' ${ }^{1}$ Mariusz Kistowski
}

1 Department of Physical Geography and Environmental Management, Faculty of Oceanography and Geography, University of Gdańsk, Bażyńskiego 4, 80-309 Gdańsk, Poland, e-mail: p.wisniewski@ug.edu.pl, geomk@univ.gda.pl

Received: 2016.05.12

Accepted: 2016.06.30

Published: 2016.09 .20

\begin{abstract}
Based on the analysis of twenty plans for a low carbon economy, adopted for implementation by the rural municipalities of typical agricultural character, representing various Polish regions, the evaluation of the role and effectiveness of these documents in the planning and coordination of activities in favor of a low carbon rural development was carried out. Evaluated among others are the scope and extent of regard for agriculture and rural areas in the diagnostic and programming parts of plans, sources of financing and monitoring indicators of individual actions. Both the advantages and disadvantages of these documents were pointed out and recommendations for drawing them up were formulated. The proposals can be a model solution for the recognition of agriculture and rural areas in a low carbon economy plans prepared by local government units.
\end{abstract}

Keywords: low carbon economy plans, low carbon development, rural areas, rural communities, agriculture.

\section{INTRODUCTION}

Poland, in pursuing the aims of the EU climate policy as well as desiring to meet new challenges, must be prepared for the need to move toward a low carbon economy. The development of such an economy requires the integration of all aspects encompassing low carbon technologies and practices, efficient energy solutions, clean and renewable energy as well as environmentally friendly technological innovations.

In order to transform the economy, appropriate actions should be planned at the local level. For this purpose, the municipal plans for low carbon economy are drawn up. They are important strategic documents, aiming to determine the vision of municipal development towards a low carbon economy as well as increase the chances of local authorities in applying for EU funds in the financial perspective 2014-2020. The tasks included in the plans should focus on low carbon and resource-efficient activities, which are to improve energy efficiency and use of renewable energy sources in all sectors of the economy with the participation of entities which are producers and consumers, residents, local authorities and institutions. Meanwhile plans are currently being developed, to pay particular attention to issues relating to energy, construction and transport, while agriculture and rural areas are treated marginally.

The aim of the study is to assess the role and importance of municipal plans for a low carbon economy in programming and coordinating the measures for a low carbon rural development and to indicate the proposals that could be a model solution for the recognition of agriculture and rural areas in such documents drawn up by the local government units.

\section{MATERIAL AND METHODS}

The analysis included twenty plans for a low carbon economy, adopted for implementation by 
the rural municipalities of typical agricultural character, representing various Polish regions (Table 1). We assessed the scope and extent of measures for the development of a low carbon economy in the agricultural and rural areas (including forestry) considering the objectives, priorities and implementation schedules in these documents. Moreover, we also examined, as indicated in the plans, measures necessary to achieve its objectives, including the legal and economic mechanisms, financial resources as well as monitoring indicators for the planned tasks.

Assessing the scope of measures for a low carbon economy included in the analyzed plans as well as methods and the degree of their implementation, particular attention was paid to:

- inclusion of agriculture and rural areas in the baseline inventory of greenhouse gas emissions,

- inclusion of agriculture and rural areas in the characteristics of the municipality and the diagnosis of local conditions,

- inclusion of agriculture and rural areas in the strategic objectives and priority directions of low carbon development of municipalities,

- inclusion of measures for a low carbon development in the agricultural and rural areas in the implementation schedules,

- indication of the bodies responsible for the implementation of specific measures,

- indication of funding sources.

Each of the above-mentioned aspects evaluated - if it has been considered in the plans whether it was done sufficiently or insufficiently.

An attempt is made also to approximate complex evaluation value of the inclusion of the problems of agriculture and rural areas in the studied plans, using relative methods of evaluation. Each of the analyzed aspects was evaluated at 1 when considered sufficient, 0.5 - when considered insufficiently and at 0 if it is not considered. Then, those assessments were summed. The scope of the sum is from 0 to 7 , with an interval of 0.5 . For the purpose of comprehensive assessment adopted the following scale the degree of inclusion of the problems of agriculture and rural areas in the low carbon economy plans:

- 0 points - rating 0 - not considered,

- $0.5-1.0$ points - rating 1 - very low,

- $1.5-2.5$ points - rating 2 - low,

- 3.0-4.0 points - rating 3 - average,

- 4.5-5.5 points - rating 4 - high,

- 6.0-7.0 points - rating 5 - very high.
The proposed model solution for the effective inclusion of agriculture and rural areas into the local planning of a low carbon economy is, among others, the result of the research and analyses carried out, as a co-author, during the work on a Pilot programme of low carbon development of Starogard county, accomplished in the years 2014-2015 within the framework of the project "Good Climate for Counties" by the Institute for Sustainable Development, Association of Polish Counties and the Community Energy Plus in cooperation with the society, authorities and institutions of the Starogard county. It is the first such document dedicated to low carbon economy, drawn on a scale county in Poland. Agriculture and rural areas (including forestry) are one of its main areas of activity and a significant development axis [Fundacja... 2015b].

\section{RESULTS AND DISCUSSION}

In most of the analyzed plans for low carbon economy, in the section on the characteristics of the municipality, an overall assessment of the condition of agricultural production space was made. In none of them, however, was a detailed diagnosis of the situation of agriculture and rural areas in terms of opportunities for development of low carbon economy performed. In five documents (for municipalities of Bestwina, Izbicko, Karczmiska, Sawin and Skrwilno) there is exclusive restriction to the characteristics of the structure of land use or value in use of soils. In six plans agriculture and rural areas have been neglected in the analysis of the local conditions (Table 2). Only in two documents, has the agricultural sector been included in the base inventory of greenhouse gas emissions, which allows for identification of the main sources of emissions and to select appropriate measures to reduce them. The plan drawn up for municipality of Aleksandrów Kujawski, included the assessment of the level of $\mathrm{CO}_{2}$ emissions from agriculture, however, it was done along with the emission from residential buildings. In the case of Izbicko municipality, the assessment was limited only to the level of $\mathrm{CO}_{2}$ emissions, which resulted from the use of agricultural tractors. In both cases, the methodology used and the adopted emission factors were not presented. There was only a reference to the guidelines contained in the Covenant of Mayors for sustainable energy economy at the local level 
Table 1. General characteristics of the municipalities covered by the analysis

\begin{tabular}{|c|c|c|c|c|c|c|}
\hline \multirow[t]{2}{*}{ Municipality } & \multirow[t]{2}{*}{ County } & \multirow[t]{2}{*}{ Voivodeship } & \multicolumn{2}{|c|}{$\begin{array}{l}\text { The percentage in } \\
\text { the general area of } \\
\text { municipality }\end{array}$} & \multirow{2}{*}{$\begin{array}{l}\text { Number of } \\
\text { farms }\end{array}$} & \multirow{2}{*}{$\begin{array}{l}\text { Number of business } \\
\text { entities involved in } \\
\text { agriculture, forestry, } \\
\text { hunting and fishing }\end{array}$} \\
\hline & & & $\begin{array}{l}\text { agricultural } \\
\text { areas }\end{array}$ & woodland & & \\
\hline $\begin{array}{l}\text { Aleksandrów } \\
\text { Kujawski }\end{array}$ & Aleksandrów & Kuyavian-Pomeranian & 74 & 16 & 1443 & 35 \\
\hline Bestwina & Bielsko & Silesian & 65 & 11 & 1640 & 18 \\
\hline Bolesławiec & Bolesławiec & Lower Silesian & 41 & 40 & 1882 & 73 \\
\hline Gietrzwałd & Olsztyn & Warmian-Masurian & 37 & 48 & 400 & 50 \\
\hline Izbicko & Strzelce & Opole & 51 & 38 & 523 & 29 \\
\hline Karczmiska & Opole Lubelskie & Lublin & 72 & 22 & 1543 & 8 \\
\hline Komorniki & Poznań & Greater Poland & 73 & 16 & 714 & 44 \\
\hline Lubartów & Lubartów & Lublin & 57 & 36 & 2494 & 25 \\
\hline Małkinia Górna & Ostrów Mazowiecka & Masovian & 60 & 29 & 1750 & 44 \\
\hline Morawica & Kielce & Świętokrzyskie & 64 & 27 & 2259 & 18 \\
\hline Nadarzyn & Pruszków & Masovian & 67 & 18 & 1043 & 18 \\
\hline Narewka & Hajnówka & Podlachia & 25 & 65 & 1433 & 23 \\
\hline Przeworsk & Przeworsk & Subcarpathian & 88 & 1 & 3608 & 15 \\
\hline Puck & Puck & Pomeranian & 60 & 29 & 1178 & 66 \\
\hline Regimin & Ciechanów & Masovian & 69 & 20 & 771 & 23 \\
\hline Sawin & Chełm & Lublin & 69 & 24 & 1707 & 24 \\
\hline Skrwilno & Rypin & Kuyavian-Pomeranian & 66 & 25 & 980 & 27 \\
\hline Sułoszowa & Kraków & Lesser Poland & 89 & 7 & 1313 & 23 \\
\hline Świecie nad Osą & Grudziądz & Kuyavian-Pomeranian & 83 & 8 & 435 & 26 \\
\hline $\begin{array}{l}\text { Tomaszów } \\
\text { Mazowiecki }\end{array}$ & $\begin{array}{l}\text { Tomaszów } \\
\text { Mazowiecki }\end{array}$ & Lodz & 45 & 44 & 2129 & 41 \\
\hline
\end{tabular}

[Bertoldi et al. 2010], in which, however, there is a reference to methodology and emission factors for agriculture and rural areas.

According to the assessment carried out among the goals and directions of low carbon development set by the studied municipalities, the measures in the field of agriculture and rural areas are limited almost exclusively to the increase in the use of biomass in the production of electricity and heat as well as the development of energy crops. In the Aleksandrów Kujawski municipality, the construction of agricultural biogas plants was planned, while in the municipality of Komorniki, we can expect that the development of a low carbon economy in rural areas will be done on the basis of the increase of green areas and forest cover, the introduction of trees stands as well as creation of forest ecological corridors. Measures for the development of low carbon economy, planned by municipalities, in most cases have not been included in the implementation schedules (Table 2). Neither were the bodies directly responsible for the execution of specific tasks indicated. Of all the studied plans, only three (municipalities of Regimin, Tomaszow Mazowiecki and Przeworsk), indicated potential sources of funding for the goals in the analyzed area. These include inter alia EU funds, funds from the programs of the National Fund for Environmental Protection and Water Management, local governments' own resources as well as those of land owners and entities operating in agriculture. Seven documents (for municipalities of Aleksandrów Kujawski, Bestwina, Gietrzwałd, Izbicko, Komorniki, Nadarzyn and Puck) indicated only the financing instruments of all the proposed activities, without reference to specific tasks. In other cases, none of the sources of funding were indicated. A lack of adopted indicators for monitoring the effects of planned activities is a weakness of most of the analyzed plans (Table 2).

A comprehensive assessment of inclusion of the problems of agriculture and rural areas in the low carbon economy plans indicates its low level. Half of the analyzed plans include this subject in a very weakly way or do not contain it at all (as the plan drawn up for municipality of Małkinia Górna). A relatively small number of analyzed 
Table 2. The scope and extent of regard for agriculture and rural areas in selected elements of municipal plans for low carbon economy

\begin{tabular}{|c|c|c|c|c|c|c|c|c|}
\hline Municipality & 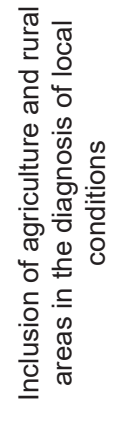 & 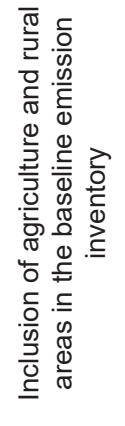 & 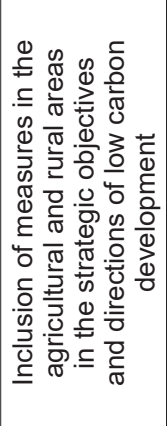 & 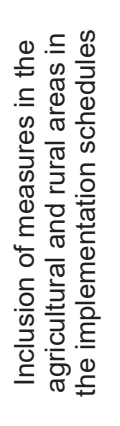 & 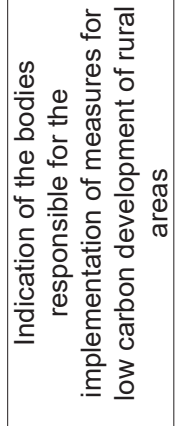 & 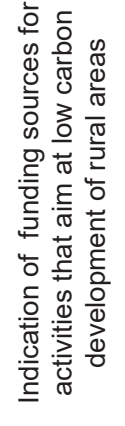 & 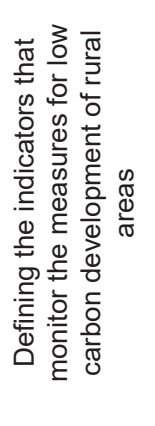 & 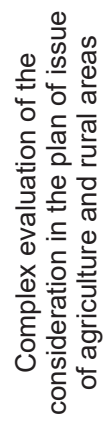 \\
\hline $\begin{array}{l}\text { Aleksandrów } \\
\text { Kujawski }\end{array}$ & $\bullet$ & $\circ$ & $\bullet$ & $\bullet$ & & $\circ$ & • & 4 \\
\hline Bestwina & $\circ$ & & $\bullet$ & & & ० & & 2 \\
\hline Bolesławiec & $\bullet$ & & & & & & & 1 \\
\hline Gietrzwałd & $\bullet$ & & $\bullet$ & - & & $\circ$ & $\bullet$ & 4 \\
\hline Izbicko & $\circ$ & o & $\bullet$ & & & $\circ$ & $\bullet$ & 3 \\
\hline Karczmiska & ० & & & & & & & 1 \\
\hline Komorniki & & & $\bullet$ & & & $\circ$ & & 2 \\
\hline Lubartów & & & $\bullet$ & & & & & 1 \\
\hline Małkinia Górna & & & & & & & & 0 \\
\hline Morawica & & & $\bullet$ & & & & & 1 \\
\hline Nadarzyn & & & $\bullet$ & & & $\circ$ & & 2 \\
\hline Narewka & $\bullet$ & & & & & & & 1 \\
\hline Przeworsk & $\bullet$ & & $\bullet$ & & & $\bullet$ & & 3 \\
\hline Puck & $\bullet$ & & - & & & o & & 2 \\
\hline Regimin & $\bullet$ & & $\bullet$ & & & $\bullet$ & & 3 \\
\hline Sawin & $\circ$ & & & & & & & 1 \\
\hline Skrwilno & $\circ$ & & & & & & & 1 \\
\hline Sułoszowa & $\bullet$ & & & & & & & 1 \\
\hline Świecie nad Osą & $\bullet$ & & & & & & & 1 \\
\hline \begin{tabular}{|l} 
Tomaszów \\
Mazowiecki
\end{tabular} & & & $\bullet$ & $\bullet$ & & $\bullet$ & & 3 \\
\hline
\end{tabular}

- - indicated/considered sufficiently, $\circ$ - indicated/considered insufficiently.

The scale of the complex evaluation of the consideration in the plan of issue of agriculture and rural areas: 0 none, 1 - very low, 2 - low, 3 - average, 4 - high, 5 - very high.

plans do not allow to draw conclusions about the spatial layout plans of varying quality, but initially it can be stated that the plans very poorly implement issues predominate in the Eastern Polish voivodships (Lublin, Podlachia, Świętokrzyskie) (Figure 1). As the average taking into account the problems of agriculture and rural areas rated plans drawn up for municipalities of: Izbicko, Przeworsk, Regimin and Tomaszów Mazowiecki, situated in different parts of the country, and the high degree taken into account in only two plans: for municipalities of Aleksandrów Kujawski and Gietrzwałd. Generally, municipalities with higher assessed plans predominate in the central belt of the country, about the course from the north (Warmia), via the Lodz Voivodeship, to the south (Opole Voivodeship). In none of the analyzed plans, the consideration of the issues of agriculture and rural areas not rated as very high (Figure 1).

In view of this analysis, there is an urgent need to develop and implement a low carbon model for rural development. In order to ensure that the municipal plans for low carbon economy becomes its effective element, they should have a substantial value, consistent with the National Programme for Development of Low Carbon Economy [Ministerstwo... 2015] and specific objectives of the Strategy for Sustainable Development of Rural 


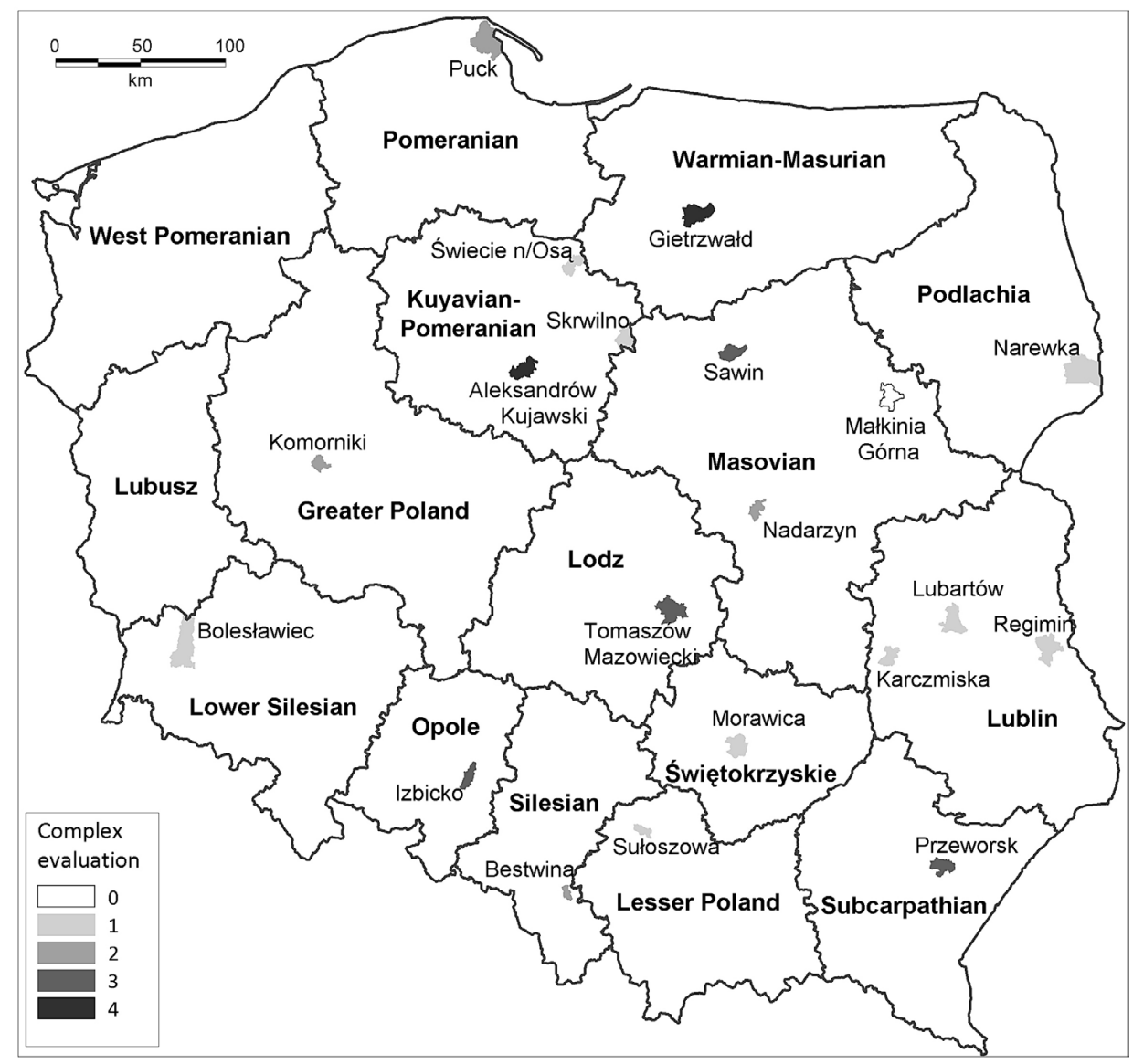

Figure 1. The complex evaluation of the consideration in the local low carbon economy plans of issue of agriculture and rural areas

Extent: 0 - none, 1 - very low, 2 - low, 3 - average, 4 - high

Areas, Agriculture and Fisheries 2012-2020 [Ministerstwo... 2012]. Moreover, they should also be consistent with local planning and strategic documents in the area of energy planning, programming of environmental protection and spatial planning and development [Wiśniewski 2015b]. They should include a complete diagnosis of the situation of agriculture and rural areas of the municipality in terms of low carbon economy, and program proposals indicating specific objectives, principles of operation of the low carbon economy as well as the main directions of low carbon development of rural areas. They should indicate the key investment needs, soft and institutional activities as well as sources of funding and ways of monitoring the planned activities (Figure 2).

Within the framework of the diagnosis of the situation of agriculture and rural areas of the municipalities in terms of opportunities to develop low carbon economy, it is advisable to carry out a SWOT analysis identifying strengths and weaknesses and the opportunities and threats in the two key elements, such as maintenance or increase in the ability to absorb $\mathrm{CO}_{2}$ as well as reduction of greenhouse gas emissions from agriculture and soil. Within the framework of the diagnosis, one should also assess the level of greenhouse gas emissions in agriculture and make warning projection, taking into account, inter alia, the changing market conditions, changes in agricultural policy, changes in the trends in livestock, volatility of prices of animal feed and unpredictability of supply and demand, potential prosperity, as well as structural changes in the country. The calculation of the carbon footprint should be made in accordance with the methodology of the IPCC (Intergovernmental Panel on Climate Change) [IPCC 2006], and also - in order to obtain more accurate data on the issue - based on the national methodology and emission factors developed by KOBiZE (The National Centre for Emissions Management) for the establishment of the annual inventory reports [Fundacja... 2015a].

When planning the main directions of low carbon development for rural areas, one should aim primarily at: 


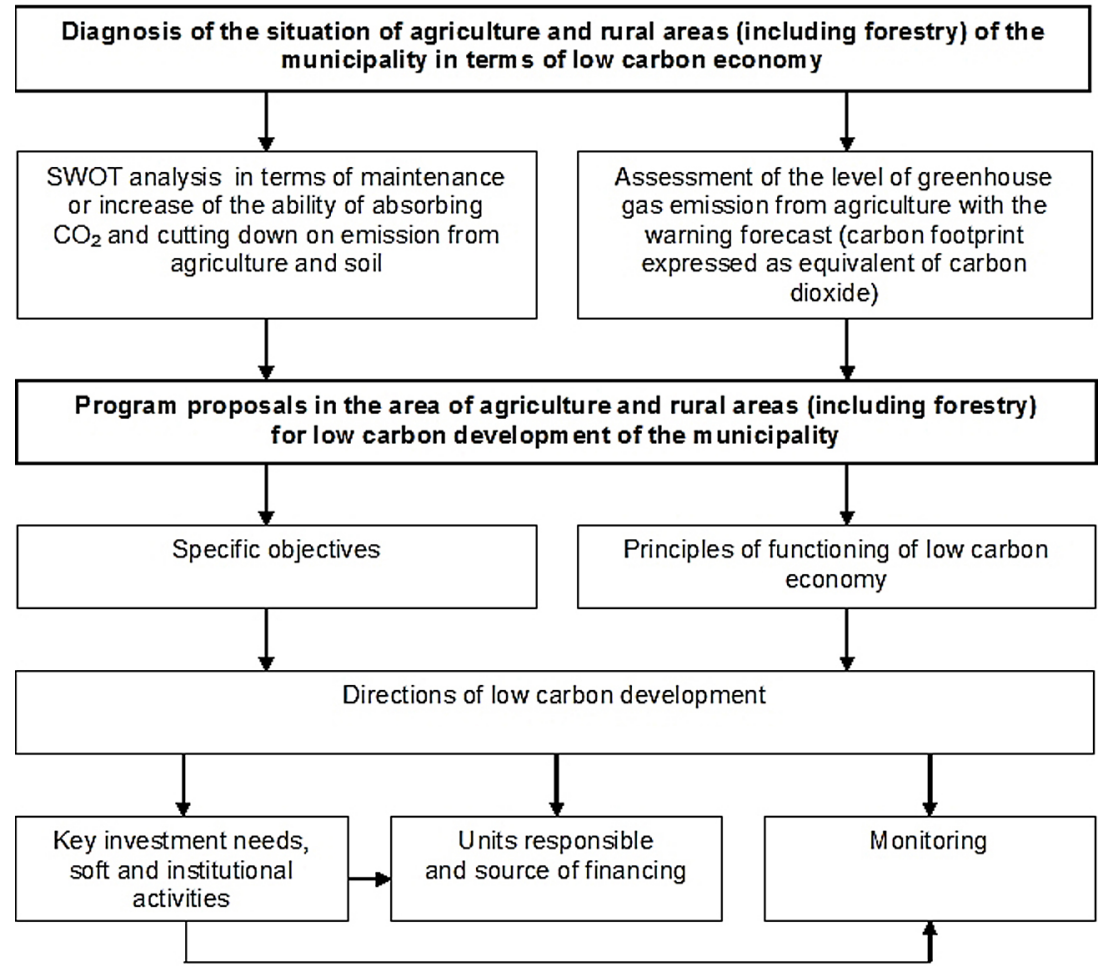

Figure 2. Model solution for agriculture and rural areas (including forestry) in municipal plans for low carbon economy

- full exploitation of the potential areas of agricultural and forestry of the municipalities for an increase in the sequestration of carbon in biomass and soil,

- bringing organic matter to the soil while reducing its losses,

- optimization of storage systems, transport and distribution of animal feces in the fields and their appropriate management,

- extensive use of agricultural activities and agro-food processing for the sake of the development of renewable energy (including the production of biogas and biofuels),

- significant improvement of energy efficiency and increase in the share of renewable energy in crop production and livestock [Wiśniewski 2015a].

Measures for low carbon development of rural areas, included in the implementation schedules of municipal plans for low carbon economy, should lead primarily to:

- increase in the use of manure and organic fertilizers by farmers (e.g. compost and green manure plowing),

- growing importance, in the production of plants with positive rate of reproducing soil organic matter and the use of fallow land and land set aside as well as waste land for growing energy crops,

- increase in green areas and woodland,

- the implementation of afforestation and creation of wildlife ecological corridors, particularly in areas with poor sandy soils susceptible to erosion,

- enhancing forest resilience through proper care of newly established forest plantations, the introduction of admixture and biocenotic species in afforestation and preventing the fragmentation of forest complexes. In areas where there are re-planted pine monocultures, one should pursue systematic reconstruction of forest stands in order to improve the soil's water conditions as well as soil-protection and soil-forming functions,

- increase in carbon sequestration in the soil, in particular, by preventing erosion and striving to maintain the correct structure and soil fertility by fertilizer components,

- decrease in acidification of agricultural soils, among others, by liming of the acidic and highly acidic soils,

- antierosion protection of soils using planning and strategic documents, application of antierosion agro-technology and phyto-irrigation in the areas at risk of erosion, 
- enhancing the retention capacity of the soil in rural areas in an integrated protection against flooding, erosion and drought,

- bringing organic matter to the soil while reducing its losses, particularly by increasing production of biomass, use of organic fertilizers, introduction of grassland and the application of appropriate agricultural practices such as mulching, conservative plowing or no plowing, maintenance of vegetation cover of the soil or leaving plant residues on it,

- increase in farmers' interest in improving the techniques of animal nutrition, appropriate balance of feed rations and adding nitrogen- binding compounds to feed preparation, as well as the use of manure plates and slurry tanks; improvement of animal husbandry systems and lowering methane emissions from stored manure and slurry,

- the construction of agricultural biogas plants, particularly small ones, by farmers (in a network),

- implementation of intelligent precision farming techniques in sustainable crop production, new production technologies, the use of natural fertilizers, minerals and plant protection products, as well as new plant varieties, breeding techniques and agro-technical procedures in conditions of climate change,

- increase in knowledge and awareness of students of agricultural schools and farmers in the field of low carbon economy in rural areas and renewable energy sources in agriculture.

The primary role in monitoring the effectiveness of the implementation of plans for a low carbon economy should be played by the indicators adopted in these plans, grouped using a common concept of the division of environmental indicators into three functional groups: pressure on the environment, the quality (of the environment) and the response to the sozological problems manifested in activities in terms of environment protection [Borys 2005, Kistowski 2006]. The set of indicators that can be used in local plans for low carbon economy, which help to evaluate emissions from crop and livestock production, the condition of the environment and the effectiveness of the implementation of the directions of low carbon development of municipalities in rural areas, are presented in the earlier work of the co-author [Wiśniewski 2015a].

\section{CONCLUSIONS}

1. The analysis of twenty plans for a low carbon economy, adopted for implementation by the rural municipalities of typical agricultural character, shows that they are currently of little importance in the shaping of low carbon development of rural areas.

2. Most analyzed documents, while proposing strategic objectives and priority directions of low carbon development in agriculture and rural areas, are limited to measures leading only to increased use of biomass in the production of electricity and heat and the development of energy crops.

3. Among the weaknesses of the studied plans for low carbon economy, we should mention first of all the exclusion of agriculture and rural areas in the diagnosis of local conditions and base inventory of greenhouse gas emissions, as well as not taking into account the planned measures in the implementation schedules. None of the analyzed plans indicated entities directly responsible for the execution of specific tasks. In most cases, the sources of financing and methods of monitoring their effectiveness were not determined.

4. It is necessary to recognize agriculture and rural areas more broadly in local plans for a low carbon economy, indicating the principles for its operation and the main directions of low carbon development of rural areas of a particular municipality, as well as the critical needs for investment, soft and institutional measures, sources of funding and carefully selected indicators for future monitoring of the degree of their implementation. For this purpose one can use the model solution, already implemented in Starogard County.

\section{REFERENCES}

1. Bertoldi P., Cayuela D.B., Monni S., Raveschoot R.P. 2010. How to develop a Sustainable Energy Action Plan (SEAP) - Guidebook. European Commission. Joint Research Centre, Luxembourg.

2. Borys T. 2005. Wskaźniki zrównoważonego rozwoju. Wydawnictwo Ekonomia i Środowisko, Warszawa-Białystok.

3. Fundacja Instytut na rzecz Ekorozwoju 2015a. Metodyka oceny poziomu emisji gazów cieplarnianych w wybranych powiatach dla lat 2005, $2010 \mathrm{i}$ 
2013 z podziałem na sektory. Warszawa.

4. Fundacja Instytut na rzecz Ekorozwoju 2015b. Pilotażowy program niskowęglowego rozwoju powiatu starogardzkiego. Warszawa.

5. IPCC 2006. 2006 IPCC Guidelines for National Greenhouse Gas Inventories. Hayama.

6. Kistowski M. 2006. Wpływ programów ochrony na środowisko przyrodnicze. Ocena jakości i ekoinnowacyjności programów ochrony środowiska województw opracowanych w latach 2001-2005. Studia nad Zrównoważonym Rozwojem T. III. Polska Akademia Nauk, Komitet „Człowiek i Środowisko” przy Prezydium PAN, Gdańsk - Warszawa.

7. Ministerstwo Gospodarki 2015. Narodowy Program
Rozwoju Gospodarki Niskoemisyjnej. Warszawa.

8. Ministerstwo Rolnictwa i Rozwoju Wsi 2012. Strategia zrównoważonego rozwoju wsi, rolnictwa i rybactwa na lata 2012-2020. Warszawa.

9. Wiśniewski P. 2015a. Rolnictwo i obszary wiejskie w lokalnym planowaniu gospodarki niskoemisyjnej na przykładzie powiatu starogardzkiego. Woda-Środowisko-Obszary Wiejskie, 4 (52), 69-81.

10. Wiśniewski P. 2015b. Zintegrowane planowanie gospodarki niskoemisyjnej w gminach. [In:] J. Maj, P. Kwiatkiewicz, R. Szczerbowski (Eds.) Między ewolucją a rewolucją - w poszukiwaniu strategii energetycznej. Fundacja na rzecz Czystej Energii, Poznań, 609-618. 